\title{
The Effect of Return on Equity and Company Size on Stock Prices with Dividend Policy as an Intervening Variable in Property and Real Estate Companies Listed in Indonesia Stock Exchange 2015-2019 Period
}

\author{
Agung Sahbana ${ }^{1}$, Galumbang Hutagalung ${ }^{2}$, Nagian Toni ${ }^{3}$, Efendy Pakpahan ${ }^{4}$ \\ ${ }^{1-4}$ Faculty of Economics, Prima Indonesia University, Medan, Indonesia \\ Corresponding Author: Galumbang Hutagalung
}

DOI: https://doi.org/10.52403/ijrr.20220304

\begin{abstract}
The purpose of this study is to test whether Return on Equity and company size affect stock prices with dividend policy as an intervening variable on property and real estate listed on the Indonesia Stock Exchange in 2015-2019 using Sobel test and path analysis. This research is a quantitative research. The total population of property and real estate companies listed on the $\mathrm{BEI}$ is 58 companies and the sample that meets the criteria according to purposive sampling is 14 companies. The results of this study indicate that Return on Equity has a positive influence on stock prices, company size does not affect stock prices, dividend policy does not affect stock prices, ROE does not affect dividend policy, company size does not affect dividend policy, while the indirect effect of ROE has no effect. on stock prices through dividend policy as well as company size does not affect stock prices through dividend policy.
\end{abstract}

Keywords: Return on Equity, Company Size, Stock Price, Dividend Policy

\section{INTRODUCTION}

Investors have various considerations to decide on a stock investment in the capital market. Stock price fluctuations are erratic and contain risks causing uncertainty for investors in determining their investment decisions. The high and low share value is reflected in the company's performance which is reflected in the financial performance of a company. As a tool to obtain information and as material for consideration, investors need data to consider investment decisions, one of which is using company financial statement data.

Ratio analysis is always used to find out the financial health and progress of the company every time the financial statements are published. Ratio analysis compares (1) the elements of the balance sheet (2) the elements of the income statement (3) the elements of the balance sheet and profit and loss, and (4) the financial ratios of one issuer with the financial ratios of other issuers. From the income statement and balance sheet, financial ratios can be prepared according to the interests of investors (Hery, 2015:132).

The purpose of financial statements according to Hans (2016:126) is to provide information about the financial position, financial performance, and cash flows of entities that are useful for most users of financial statements in making economic decisions. According to Hutauruk (2017:10) the purpose of financial statements is to provide information regarding the financial position, performance and changes in the financial position of an entity that is useful for a large number of users in making economic decisions. 
Meanwhile, according to Jogiyanto (2008:167) the stock price is the price of a share that occurs in the stock market at a certain time determined by market participants and determined by the demand and supply of the shares concerned in the capital market. Darmadji and Fakhrudin (2012:102) state that the stock price is the price that occurs on the stock exchange at a certain time. According to Zubir (2013), stock prices are a reflection of good corporate management by management to create and utilize business prospects, so that they gain profits and are able to fulfill their responsibilities to owners, employees, society and the government (stakeholders). Meanwhile, according to Tandelilin, (2010: 383) share price is the money spent to obtain proof of participation or ownership of a company.

The following is an overview of property and real estate stock price movements for the 2015-2019 period.

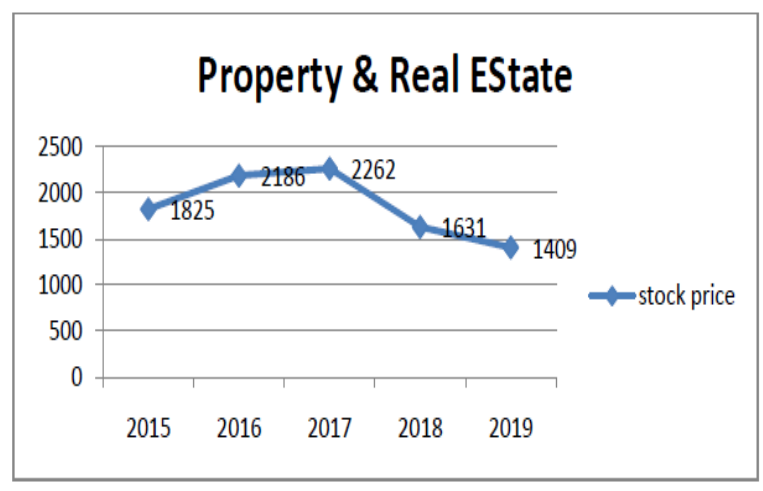

Picture 1Property and Real Estate Share Prices 2015-2019 Source: Processed Data, 2021

Based on Figure 1, it can be seen that stock prices in 2015-2017 tended to increase, but in 2018 and 2019 they tended to move down significantly.

An investor who will invest his funds in a particular company, should perform an analysis of the performance of the company concerned. The company's financial performance needs to be analyzed first so that investors are not wrong in choosing stocks and are stuck with stocks with poor financial conditions. The better the performance of a company, the greater the influence on the increase in stock prices.
Vice versa, the lower the performance of a company, the more likely the price of shares issued and traded will decline. The state of the company will be a measure of how much risk will be borne by investors. To determine whether the condition of the company is in a good or bad position by using fundamental analysis through ratio analysis, one of which is ROE and Company Size.

Return On Equity (ROE) is used to measure the amount of return on investment by shareholders. This ratio shows how well management utilizes shareholders' investments. ROE is a comparison between income after tax with own capital. The increase in ROE is usually followed by an increase in the stock price of a company. The greater the ROE, the greater the stock price because the large ROE indicates that the returns to be received by investors will be high so that investors will be interested in buying these shares and this causes the stock market price to tend to rise.

Company size is a determination of the size of the company. The higher the total assets that show the assets owned by the company, it indicates that the company is classified as a large company. And conversely, the lower the total assets indicates that the company is classified as a small company. The greater the total assets, the greater the assets owned by the company so that investors will be safe in investing or investing in the company.

There are 58 property and real estate companies listed on the Indonesia Stock Exchange, with 16 companies experiencing losses in 2015-2019.

Based on the existing theory that when profit increases (ROE), the dividend distribution policy also tends to increase because dividends are distributed based on profit, this will then be responded positively by investors which causes the share price to increase. Likewise, a company that has a large size indicates that the company is already well-established both in terms of sales and income, so that the larger the size measured by its total assets, the greater the investor's interest in the company, which 
causes its share price to also increase. It can be concluded that based on the theory that there is an increase in ROE; company size will directly affect the increase in dividend policy which will ultimately have an impact on increasing its share price. This study uses dividend policy as an intervening variable between ROE and Company Size on stock prices because companies with larger sizes are expected to have the ability to generate larger earnings, so they will be able to pay higher dividends than small companies.

Table1: Phenomenon Data on Three Property and Real Estate Companies for the 2015-2019 Period

\begin{tabular}{|c|c|c|c|c|c|}
\hline Kode & years & ROE & Company Size & Stock price & DPR \\
\hline APLN & 2015 & 0,123 & 30,832 & 334 & 0,140 \\
\cline { 2 - 6 } & 2016 & 0,094 & 30,878 & 210 & 0,124 \\
\cline { 2 - 6 } & 2017 & 0,164 & 30,991 & 210 & 0,168 \\
\cline { 2 - 6 } & 2018 & 0,017 & 31,018 & 152 & 0,857 \\
\cline { 2 - 6 } & 2019 & 0,009 & 31,014 & 177 & 1,252 \\
\hline BEST & 2015 & 0,070 & 29,164 & 294 & 0,104 \\
\cline { 2 - 6 } & 2016 & 0,099 & 29,281 & 254 & 0,035 \\
\cline { 2 - 6 } & 2017 & 0,126 & 29,375 & 250 & 0,069 \\
\cline { 2 - 6 } & 2018 & 0,101 & 29,470 & 208 & 0,228 \\
\cline { 2 - 6 } & 2019 & 0,085 & 29,487 & 216 & 0,222 \\
\hline BSDE & 2014 & 0,106 & 31,215 & 1.800 & 0,163 \\
\cline { 2 - 6 } & 2016 & 0,084 & 31,276 & 1.755 & 0,107 \\
\cline { 2 - 6 } & 2017 & 0,177 & 31,459 & 1.700 & 0,037 \\
\cline { 2 - 6 } & 2018 & 0,056 & 31,584 & 1.255 & 0,040 \\
\cline { 2 - 6 } & 2019 & 0,093 & 31,630 & 1.255 & 0,035 \\
\hline
\end{tabular}

Source: processed data

\section{LITERATURE REVIEW Stock price}

According to Gumanti (2011:4), the price of securities that are formed today is a reflection of investors' best estimates of various possible changes from various factors in the future. The stock price is the price formed on the stock exchange and in general the stock price is obtained to calculate the stock value (Kodrat and Indonanjaya, 2010:1).

According to Sutrisno (2012:309) fundamental analysis is an approach to stock price analysis that focuses on company performance. The company's performance can be seen from the company's development, the company's balance sheet and its income statement. As said by Wijayanti (2010) that stock prices change (fluctuate) in accordance with the strength of demand (demand) and supply (supply), one of the factors that influence the purchase of shares (demand) is based on fundamental considerations, namely the company's financial performance, with financial performance A good company is able to generate high profits and at the same time can set aside a share of that profit as a high dividend, so that this will affect the demand for shares.
One of the factors that affect stock prices is the condition of the company, in this case it is defined as the company's financial performance, company performance is a very important thing, because the company's performance is influential and can be used as a tool to determine whether the company is experiencing growth or vice versa. the oldest and most widely used is financial performance as measured from the company's financial statements, analysis of financial statements can be done by calculating financial ratios, the types of financial ratios that are often used in assessing the company's financial performance are liquidity ratios, activity ratios, solvency ratios, profitability ratios, and market ratios, Zuliarni (2012).

\section{Return on Equity}

According to Wahyudiono (2014: 82), Return on Equity is often also called the profitability of own capital. This ratio is used to measure how much profit belongs to the owner of his own capital. According to Gumanti (2011: 116), the rate of return on capital (return on equity) is a ratio that shows how able the company is to use existing capital to generate profits or profits. 
According to Kasmir (2016: 204) states the formula for return on equity as follows:

$$
\text { Return on Equity }=\frac{\text { Earning After Interest and Tax }}{\text { Equity }}
$$

The dividend policy indicator in this study is measured by the dividend payout ratio. According to Sudana (2015: 24), this ratio measures how much of the net profit after tax is paid as dividends to shareholders. The larger this ratio means the less part of retained earnings to finance the investments made by the company. The formula for calculating dividend policy is:

$$
\text { Dividend Payout Ratio }(\text { DPR })=\frac{\text { Dividend }}{\text { Earning After Taxes }}
$$

According to Sumarsan (2013: 53) dividend Payout Ratio can be calculated by the formula:

$$
D P R=\frac{\text { Cash dividend }}{\text { Net profit after tax }}
$$

According to Murhadi (2015:65) the dividend payout ratio formula is:

$$
D P R=\frac{\text { Dividend }}{\text { Net Income }}
$$

\section{MATERIALS \& METHODS}

This research was conducted on companies that are members of the property and real estate sector listed on the Indonesia Stock Exchange for the 2015-2019 period through intermediary media by browsing the website www.idx.co.id.

Multiple Linear Regression Analysis:

$Y=a+b_{1} X_{1}+b_{2} X_{2}+b_{3} Z+e$

$\mathrm{Z}=\mathrm{a}+\mathrm{b}_{1} \mathrm{X}_{1}+\mathrm{b}_{2} \mathrm{X}_{2}+\mathrm{e}$

\section{Description:}

Y : stock price

$\mathrm{Z} \quad$ : Dividend Policy

a : constant

b1,b2 : Regression coefficient

$\mathrm{X}_{1} \quad$ : ROE

$\mathrm{X}_{2} \quad$ : Company Size

e $\quad$ : Error percentage (\%)

\section{RESULT}

Descriptive Statistics

The number of data in this research is 14 companies in the property and real estate sector multiplied by 5 periods so that the number of observation data is 70 data. The following shows the minimum, maximum, mean and standard deviation values for each of the variables studied:

Table 2: Descriptive Statistics

\begin{tabular}{|l|c|c|c|c|c|}
\hline \multicolumn{7}{|c|}{ Descriptive Statistics } \\
\hline & $\mathbf{N}$ & Minimum & Maximum & Mean & Std. Deviation \\
\hline ROE & 70 & .009 & .323 & .11777 & .062628 \\
\hline Size & 70 & 28.036 & 31.630 & 29.94656 & .965528 \\
\hline StockPrice & 70 & 76 & 36500 & 3033.36 & 6395.489 \\
\hline DPR & 70 & .026 & 1.577 & .26289 & .319795 \\
\hline Valid N (listwise) & 70 & & & & \\
\hline
\end{tabular}

ROE has a minimum value of 0.009 which is owned by PT. Agung Podomoro Land, tbk in 2019. Maximum ROE of 0.323 owned by PT. Metropolitan Kentjana, tbk 2016. The average ROE of property and real estate companies for the 2015-2019 period is 0.11777 with a standard deviation of 0.062628 .

Size has a minimum value of 28,036 which is owned by PT. Perdana Bumi Serpong Damai, tbk in 2019. The average company size of property and real estate companies for the 2015-2019 period is
29.94656 with a standard deviation of 0.965528 .

The share price has a minimum value of Rp. 76,- which is owned by PT. Perdana Gapuraprima, tbk in 2019. The maximum share price is Rp. 36,500,- owned by PT. Metropolitan Kentjana, tbk in 2017. The average company size of property and real estate companies is IDR 3,033.36 with a standard deviation of 6395.489 .

Dividend policy proxied by Dividend Payout Ratio has a minimum value of 0.026 at PT. Intiland Development, tbk in 2018 while the maximum value is 1,577 at PT. 
Puradelta Lestari, tbk 2017. The average dividend policy of property and real estate companies for the 2015-2019 period is 0.26289 with a standard deviation of 0.319795 .

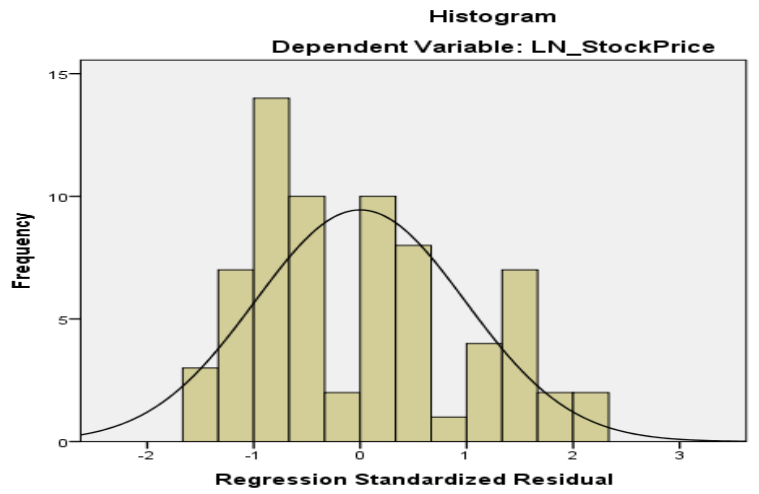

Figure2: Histogram Normality Test after Transformation Source: Data Processing Results, 2022

Figure 2 shows the curve line is symmetrical (U) and does not deviate to the left and right, so it can be said that the data is normally distributed.

In Figure 3, the dots approach the diagonal line. In addition to graph analysis, statistical analysis needs to be carried out to ensure whether the data are actually normally distributed. Statistical testing if the significant value is greater than 0.05 , it can be said that the data is normally distributed.

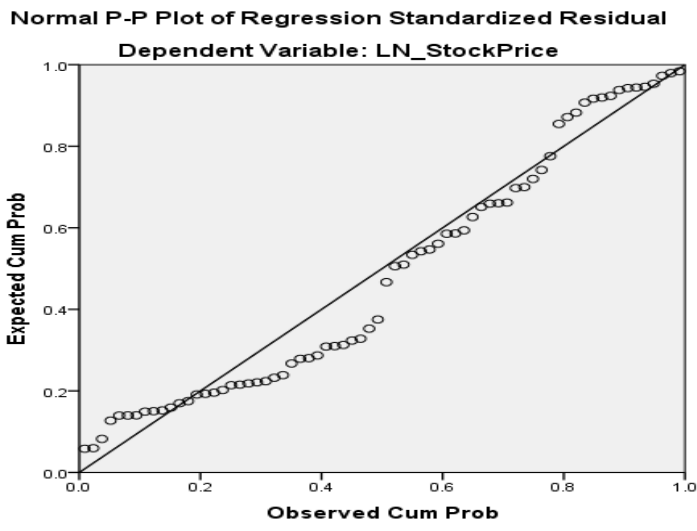

Figure3: P-P Plot Normality Test after Transformation Source: Data Processing Results, 2022

Substructural equation 1: $\mathrm{Y}=\mathrm{a}+\mathrm{b} 1 \mathrm{X} 1+$ $\mathrm{b} 2 \mathrm{X} 2+\mathrm{b} 3 \mathrm{Z}+\mathrm{e}$

Substructure equation 1 is used to examine the effect of the variables Return on Equity, company size and dividend policy (DPR) on stock prices. The results of the substructure 1 equation test can be seen in table 3 below:

Table 3: Coefficient of Determination Test Results the Effect of Return on Equity, company size and dividend policy (DPR) on Stock Prices

\begin{tabular}{|c|c|c|c|c|}
\hline \multicolumn{5}{|c|}{ Model Summary } \\
\hline Model & R & R Square & Adjusted R Square & Std. Error of the Estimate \\
\hline 1 & $.493^{\text {a }}$ & .243 & .209 & 1.31531 \\
\hline \multicolumn{5}{|c|}{ a. Predictors: (Constant), LN_DPR, LN_ROE, LN_Size } \\
Source: Data Processing Results, 2022
\end{tabular}

Based on Table 3 above, the value of $\mathrm{R}$ Square is 0.243 , which means that the ability of the Return on Equity, company size and dividend policy (DPR) variables to explain the variation of the stock price variable is $24.3 \%$ and the remaining $75.7 \%$ is explained by the variable -Other variables outside the model.

Sub structure equation $2: \mathrm{Z}=\mathrm{a}+\mathrm{b} 1 \mathrm{X} 1+$ $\mathrm{b} 2 \mathrm{X} 2+\mathrm{e}$

Substructure equation 2 is used to examine the effect of Return on Equity and
Company Size variables on dividend policy. Testing the substructure equation 2 was carried out using multiple linear regression analysis through the coefficient of determination and the $\mathrm{t}$ statistic test.

Based on Table 4 above, the value of $\mathrm{R}$ Square is 0.011 , which means that the ability of the Return on Equity and Company Size variables to explain the variation of the dividend policy variable is $1.1 \%$ and the remaining $98.9 \%$ is explained by other variables outside the model.

Table 4: Coefficient of Determination Test Results the Effect of ROE and Company Size on Dividend Policy

\begin{tabular}{|c|c|c|c|c|}
\hline \multicolumn{5}{|c|}{ Model Summary } \\
\hline Model & $\mathbf{R}$ & R Square & Adjusted R Square & Std. Error of the Estimate \\
\hline 1 & $.103^{\mathrm{a}}$ & .011 & -.019 & .89561 \\
\hline \multicolumn{5}{|c}{ a. Predictors: (Constant), LN_Size, LN_ROE } \\
\hline \multicolumn{5}{|c}{ Source: Data Processing Results, 2022 } \\
\hline
\end{tabular}




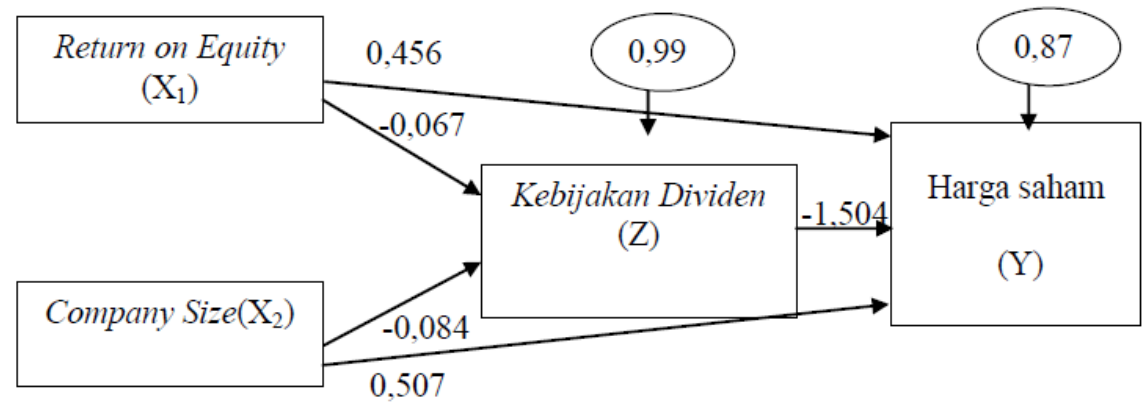

Figure 4: Path Diagram of the Effect of Current Ratio and Debt to Equity Ratio on Stock Prices with Return on Equity as Intervening Variable

Based on the path diagram in Figure 4 , it can be concluded that the structural equation is as follows:

a. Substructural equation 1: $\mathrm{Y}=0.456 \mathrm{X} 1$ $+0.507 \mathrm{X} 2-1.504 \mathrm{Z}+0.870$

b. Substructure equation $2: \mathrm{Z}=-0.067 \mathrm{X} 1-$ $0.084 \mathrm{X} 2+0.994$

\section{DISCUSSION}

\section{The Effect of Return on Equity on Stock Prices}

The results of testing the first hypothesis can be seen that Return on Equity has a positive effect on stock prices in property and real estate companies listed on the Indonesia Stock Exchange for the 20152019 period. This is indicated by the t-count value of 4.234 which is greater than the ttable value of 1.99656 and the significance value of 0.000 is smaller than the 0.05 alpha value.

The results of this study are in line with Febrianti (2020), Djuitha (2019), Hasanuddin (2020) which show that ROE has a significant positive effect on stock prices. ROE is used to measure the return on investment of shareholders. This figure shows how well management is making use of shareholders' investments. ROE is measured in percent. The ROE level has a positive relationship with stock prices, so the greater the ROE the greater the market price, because the large ROE indicates that the returns that investors will receive will be high so that investors will be interested in buying the shares, and this causes the stock market price to tend to go on.

\section{The Effect of Company Size on Stock Prices}

The results of testing the second hypothesis can be seen that company size has no effect on stock prices in property and real estate companies listed on the Indonesia Stock Exchange for the 2015-2019 period. This is indicated by the $t$ count value of 0.507 which is smaller than the table value of 1.99656 and the significance value of 0.614 which is greater than the alpha value of 0.05 . The results of this study are in line with Hasanudin (2020), namely the size of the company has no effect on stock prices.

\section{The Effect of Dividend Policy on Stock Prices}

The results of testing the third hypothesis can be seen that dividend policy has no effect on share prices in property and real estate companies listed on the Indonesia Stock Exchange for the 2015-2019 period. This is indicated by the $t$ count value of 1.504 which is greater than the t table value of -1.99656 and the significance value of 0.137 which is greater than the alpha value of 0.05 . The results of this study are in line with Megamawarni and Pratiwi (2021), Mariana (2016), namely dividend policy has no effect on stock prices.

\section{Effect of Return on Equity on Dividend Policy}

The results of testing the fourth hypothesis can be seen that Return on Equity has no effect on dividend policy in property and real estate companies listed on the Indonesia Stock Exchange for the 2015-2019 period. This is indicated by the tcount value of -0.548 which is smaller than the table 
value of -1.99601 and the significance value of 0.586 which is greater than the alpha value of 0.05 . The results of this study are in line with Megamawarni and Pratiwi (2021) which show that ROE has no effect on dividend policy.

\section{Effect of Company Size on Dividend Policy}

The results of testing the fifth hypothesis can be seen that company size has no effect on dividend policy in property and real estate companies listed on the Indonesia Stock Exchange for the 2015-2019 period. This is indicated by the tcount value of 0.688 which is greater than the table value of -1.99601 , and the significance value of 0.494 which is greater than the alpha value of 0.05 . The results of this study are in line with previous research by Handayani, et al. (2019), namely company size has no effect on the dividend payout ratio.

\section{The Effect of Return on Equity on Stock Prices through Dividend Policy}

The results of testing the sixth hypothesis can be seen that indirectly Return on Equity has no effect on stock prices through dividend policies on property and real estate companies listed on the Indonesia Stock Exchange for the 2015-2019 period. This is indicated by the $t$ arithmetic value of 0.439 which is smaller than the $t$ table of 1.96.

\section{The Effect of Company Size on Stock Prices through Dividend Policy}

The results of testing the sixth hypothesis can be seen that indirectly company size has no effect on stock prices through dividend policies on property and real estate companies listed on the Indonesia Stock Exchange for the 2015-2019 period. This is indicated by the $t$ arithmetic value of 0.536 which is smaller than the table 1.96 with a significance level of 0.05 .

\section{CONCLUSION}

Return on Equity has a positive effect on stock prices in property and real estate companies listed on the Indonesia Stock
Exchange for the 2015-2019 period. Company size has no effect on stock prices in property and real estate companies listed on the Indonesia Stock Exchange for the 2015-2019 period. The dividend policy has no effect on share prices in property and real estate companies listed on the Indonesia Stock Exchange for the 2015-2019 period. Return on Equity has no effect on dividend policy on property and real estate companies listed on the Indonesia Stock Exchange for the 2015-2019 period. Company size has no effect on dividend policy in property and real estate companies listed on the Indonesia Stock Exchange for the 2015-2019 period. Indirectly Return on Equity has no effect on stock prices through dividend policies on property and real estate companies listed on the Indonesia Stock Exchange for the 20152019 period. Indirectly, company size has no effect on stock prices through dividend policies on property and real estate companies listed on the Indonesia Stock Exchange for the 2015-2019 period.

Acknowledgement: None

Conflict of Interest: None

\section{Source of Funding: None}

\section{REFERENCES}

1. Darmadji, Tjiptono dan M. Fakhruddin, Hendy. 2012. Capital Market in Indonesia. Jakarta: Salemba Empat (PT Salemba Empat Patria)

2. Djuitha, Ribvanny. 2019. The Effect of Dividend Policy and Profitability on Share Prices in Property and Real Estate Companies Listed on the Indonesia Stock Exchange in 2012-2016. JOM FISIP Vol. 6: Issue I January-June 2019.

3. Febrianti, Y. (2020). The Effect of Profitability and Dividend Policy on Stock Prices of the Lq 45 Index of the Indonesia Stock Exchange. Journal Of Applied Accounting Research, 4(2), 206-218

4. Gumanti, Tatang Ary. 2011. Investment Management Concepts, Theories and Applications. Jakarta: Mitra Wacana Media.

5. Gumanti, Tatang Ary. 2011. Investment Management Concepts, Theories and Applications. Jakarta: Mitra Wacana Media 
6. Handayani, K. M., Indarti, I., \& Listiyowati, L. (2019). The Effect of Financial Performance and Company Size on Stock Prices with Dividend Policy as an Intervening Variable in Manufacturing Companies Listed on the Indonesia Stock Exchange. Scientific Journal of Assets, 21(2), 93-105.

7. Hans Kartikahadi. (2016). Intermediate financial Accounting. Jakarta: Salemba Empat

8. Hasanuddin, R. (2020). Effect of Capital Structure, Company Size and Profitability on Stock Prices in Food and Beverage Companies Listed on the Indonesia Stock Exchange. Celebes Equilibrum Journal, 1(2), 54-63

9. Hery. 2015. Financial Statement Analysis. Yogyakarta: CAPS (Center for Academic Publishing Service).

10. Hutauruk, Martinus Robert 2017.Company Accounting Services Application Program Zahir Accounting Version 6. West Jakarta : Index

11. Jogiyanto. (2008). Portfolio Theory and Investment Analysis. Fifth Edition, BPFE. Yogyakarta.

12. Kasmir. 2016. Financial Statement Analysis. Fifth Printing Jakarta: Penerbit PT. Raja Grafindo Persada.

13. Kodrat, D. S. dan Kurniawan Indonanjaya. 2010. Investment Management (Technical and Fundamental Approaches To Stock Analysis). Yogyakarta: Graha Ilmu

14. Mariana, C. (2017). The Effect of Financial Performance and Dividend Policy on Stock Prices (Survey of Property and Real Estate Sector Companies on the Indonesia Stock Exchange (IDX) in 2013). JIA (Journal of Scientific Accounting), 1(1).

15. Megamawarni, M., \& Pratiwi, A. (2021). The Effect of Financial Ratios and Company Growth on the Dividend Payout Ratio (DPR) and Its Implications on Stock Prices of
Banking Companies Listed on the Indonesia Stock Exchange (IDX). Journal of Maksipreneur: Management, Cooperatives, and Entrepreneurship, 11(1), 47-68.

16. Sri Zuliarni. 2012. The Effect of Financial Performance on Stock Prices in Mining and Mining Service Companies on the Indonesia Stock Exchange (IDX). Journal of Business Applications Vol. 3 No. 1, October 2012.

17. Sudana, I Made. 2015. Corporate Financial Management: Theory \& Practice. Jakarta: Penerbit Erlangga.

18. Sumarsan, Thomas. 2013. Indonesian Taxation: Edition 3.Jakarta : PT.Index

19. Sutrisno. 2012. Financial Management Theory Concepts and Applications. Yogyakarta: Econesia.

20. Tandelilin, Eduardus. 2010. Portfolios and Investments: Theory and Applications. Issue 1. Canisius. Yogyakarta.

21. Wahyudiono, Bambang. 2014. Easy to Read Financial Statements. Jakarta: Raih Asa Sukses.

22. Wijayanti, Martina P.. 2010. "Auditor-Client Relationship Analysis: Factors Affecting Auditor Switching in Indonesia". S1 Thesis, Faculty of Economics, Diponegoro University, Semarang.

23. Zubir, Z. (2013). Portfolio Management: Its Application in Stock Investment. Jakarta: Penerbit Salemba Empat

How to cite this article: Agung Sahbana, Galumbang Hutagalung, Nagian Toni et.al. The effect of return on equity and company size on stock prices with dividend policy as an intervening variable in property and real estate companies listed in Indonesia Stock Exchange 2015-2019 period. International Journal of Research and Review. 2022; 9(3): 24-31. DOI: https://doi.org/10.52403/ijrr.20220304 